\title{
Relationship Between Naturally Occurring T Lymphocytotoxic Antibodies in Viral and Related Diseases and Their Target T Lymphocyte Subsets
}

\author{
Hiroshi Hosokawa, Sumihito Horio, Yasuko Takiuchi ${ }^{1}$, \\ Naoki Maruyama ${ }^{2)}$, and Yasuo Asada \\ Department of Dermatology, Kansai Medical University, Moriguchi, Osaka 570 Japan \\ 1) Department of Medicine, Seikyo Juso Hospital, Osaka, Japan \\ 2) Department of Pathology, Tokyo Metropolitan Institute of Gerontology, Tokyo, Japan
}

(Received for publication November 24, 1987)

Key words : $\mathrm{T}$ lymphocytotoxic antibodies, $\mathrm{T}$ lymphocyte subsets, Viral Infection, Nasopharyngeal carcinoma, SLE

\begin{abstract}
Naturally occurring $\mathrm{T}$ lymphocytotoxic antibodies ( $\mathrm{T}-\mathrm{LCA}$ ) have been detected in a variety of diseases including autoimmune diseases, viral infections and the acquired immune deficiency syndrome (AIDS). This study was undertaken to determine whether T-LCA in viral and related diseases are directed against a particular subset of $\mathrm{T}$ cells. After lysis of normal $\mathrm{T}$ cells with T-LCA and complement, the residual $\mathrm{T}$ cell population was studied using a series of $\mathrm{T}$ cell subset specific monoclonal antibodies. Our results indicate that T-LCA present in viral exanthema, pityriasis rosea and systemic lupus erythematosus (SLE) may be preferentially directed against OKT -8 (suppressor/cytotoxic) positive $\mathrm{T}$ cells, whereas those of nasopharyngeal carcinoma may be preferentially directed against OKT-4 (helper/inducer) positive $\mathrm{T}$ cells. These findings suggest that different reactivities of T-LCA with T cell subsets are dependent upon a variety of factors. It is also noted that the sera of patients with nasopharyngeal carcinoma showed higher titers of T-LCA than those of patients with viral exanthema and pityriasis rosea.
\end{abstract}

\section{Introduction}

The lymphocytotoxic antibodies (LCA) have been observed in a variety of diseases including autoimmune diseases ${ }^{1,2)}$, viral infections ${ }^{3}, 4$ ) and the acquired immune deficiency syndrome (AIDS) $5,6,7$ ). Recent studies demonstrated that $T$ lymphocytotoxic antibodies (T-LCA) found in the sera of active SLE patients were selectively reactive with OKT-8 (suppressor/ cytotoxic) positive $\mathrm{T}$ cell population and patients with active SLE had decreased number of OKT-8 positive $\mathrm{T}$ cell subset $^{8,9)}$. 
Our previous study demonstrated that T-LCA detected in viral and related tkin diseases were similar in nature to those of SLE patients, but were transient and lower in titer than those of $\mathrm{SLE}^{10)}$. However, there are few reports on the relationship between T-LCA in patients with viral and related diseases and the target $T$ cell subsets ${ }^{5,6,7)}$.

This study was undertaken to determine whether T-LCA in viral and related diseases are directed against a paticular subset of $\mathrm{T}$ cells.

\section{Materials and Methods}

\section{Patients and sera}

Sera were obtained from 3 patients with viral exanthema, 2 with pityriasis rosea, 3 with nasopharyngeal carcinoma (NPC), 5 with SLE and 10 healthy adults. Sera of NPC were gifts from Dr. Eiji Tatsumi (Department of Internal Medicine, Kyoto Univesity). We found that all these sera contained T-LCA, except those of healthy adults. All patients with viral exanthema and pityriasis rosea were diagnosed by clinical features and laboratory data. Three patients with NPC diagnosed by otorhinolaryngologists had Epstein-Barr virus associated antibodies. Patients with SLE met the revised criteria for the classification of SLE ${ }^{11)}$. All sera were stored at $-80^{\circ} \mathrm{C}$ until use.

\section{Detection and characterization of T-LCA}

E-rosette inhibition test (ERIT) : The presence of $\mathrm{T}$ lymphocytotoxic antibody was detected by the ability of sera to inhibit E-rosette formation of peripheral blood lymphocytes (PBL) and was evaluated by the modified $\operatorname{method}^{12)}$ of Koike et $\mathrm{al}^{13)}$. PBL were obtained from heparinized venous blood by Ficoll-Hypaque density gradient centrifugation. A mixture of $25 \mu 1$ of $\mathrm{PBL}$ suspension $\left(5 \times 10^{6}\right.$ cells $\left./ \mathrm{ml}\right)$ and $50 \mu \mathrm{l}$ of serum at varying dilutions was incubated at $15^{\circ} \mathrm{C}$ for $30 \mathrm{~min}$ (first incubation). Next, $50 \mu \mathrm{l}$ of rabbit complement was added. After incubation for 3 hours (second incubation), the cells were then washed once in RPMI-1640 medium, and tested for sheep erythrocyte (E)-rosette formation as previously described by Mendes et $\mathrm{al}^{14)}$. After overnight incubation at $4^{\circ} \mathrm{C}$, the cells were gently resuspended, and $\mathrm{E}$-rosette forming cells $(\mathrm{RFC})$ were counted on prestained slide (Blutstan, Daiichi Pure Chemicals, Japan). More than 200 lymphocytes were counted, and the lymphocytes binding $3 \mathrm{SRBC}$ or more were regarded as positive RFC. As controls, PBL were treated with serum alone or with the complement alone. Sera which showed more than $20 \%$ inhibition were considered to be positive. Percentage of E-rosette inhibition was calculated as follows :

$$
\% \text { inhibition }=\left(1.0-\frac{\text { Serum treted } \% \mathrm{RFC}}{\text { Untreated } \% \mathrm{RFC}}\right) \times 100(\%)
$$

2-Mercaptoethanol (2-ME) treatment of sera : A mixture of an equal volume of $0.2 \mathrm{M} 2-\mathrm{ME}$ 
$S-46$

and the serum was incubated for $15 \mathrm{~min}$ at $37^{\circ} \mathrm{C}$ followed by incubation for 4 hours at room temperature, and then dialysed with phosphate buffered saline overnight. These sera were then tested by ERIT.

\section{Identification of $\mathbf{T}$-LCA reactive $\mathbf{T}$-cell subset}

Isolation of $\mathrm{T}$ lymphocytes: $\mathrm{T}$ lymphocytes were isolated by passing $\mathrm{PBL}$ over nylon wool columns (Bosei Science, Japan) and collecting the nonadherent population, according to the technique of Julius et $\mathrm{al}^{15)}$. The $\mathrm{T}$ cell population obtained was $85 \%$ reactive with monoclonal antibody OLT-3 (Ortho Pharmaceuticals, Raritan NJ, USA), which detects an antigen present on all mature peripheral $\mathrm{T}$ lymphocytes.

Complement-dependent lysis of $\mathrm{T}$ lymphocytes with serum $: 6 \times 10^{5} \mathrm{~T}$ lymphocytes were incubated in $300 \mu \mathrm{l}$ of serum for 1 hour at $15^{\circ} \mathrm{C}$. Then, an equal volume of rabbit complemeot was added to each tube, and the cells were incubated for an additional 3 hours at $15^{\circ} \mathrm{C}$. The lysed cells were then washed and subsequently placed in RPMI-1640 medium.

Analysis of residual $\mathrm{T}$ cells with monoclonal antibodies: After being treated with sera and rabbit complement, $\mathrm{T}$ cells were identified with monoclonal antibodies (OKT-4, OKT-8) by indirect immunofluorescence according to the procedure described in the manufacture's technical information sheet. Killing ratios of $\mathrm{OKT}-4 / \mathrm{OKT}-8$ by patient's sera were calculated and compared with those of healthy controls. The killing ratio of OKT $-4 / \mathrm{OKT}-8$ was calculated as follws:

$$
\text { OKT }-4 / \mathrm{OKT}-8 \text { killing ratio }=\frac{\text { Serum treated } \mathrm{OKT}-4 / \mathrm{OKT}-8 \text { ratio }}{\text { Untreated } \mathrm{OKT}-4 / \mathrm{OKT}-8 \text { ratio }}
$$

\section{Statistical analysis}

Student's t-test was used to calculate the statistical significance between data in the disease groups and healthy controls. Nonsignificant differences were $p>0.05$.

\section{Results}

\section{Detection and characterization of T-LCA}

Data displayed in Table I show that all sera in the present study contained T-LCA as shown before 2-ME treatment. It is noted that sera from patients with NPC contained T-LCA. All 11 sera trated with 2-ME markedly decreased the activities of E-rosette inhibition (Table I).

\section{Identification of T-LCA reactive $T$ cell subset}

After lysis of normal $\mathrm{T}$ cells with sera and complement, the residual $\mathrm{T}$ cell population was studied using a series of $\mathrm{T}$ cell subset specific monoclonal antibodies to determine whether a specific subset of human $\mathrm{T}$ cells had been eliminated. It was demonstrated that killing ratios 
Table I Detection of naturally occurring T lymphocytotoxic antibodies (T-LCA) and effect of 2 -mercaptoethanol treatment on T-LCA in sera of patients with viral and related diseases and SLE.

\begin{tabular}{lcc}
\hline & \multicolumn{2}{c}{ 2-ME treatment } \\
\cline { 2 - 3 } Diagnosis & $\begin{array}{c}\text { Before } \\
(\%)\end{array}$ & $\begin{array}{c}\text { After } \\
(\%)\end{array}$ \\
\hline Viral exanthema no. 1 & $50^{\mathrm{a}}$ & 0 \\
Viral exanthema no. 2 & 48 & 8 \\
Viral exanthema no. 3 & 33 & N.D. $\mathrm{b}$ \\
Pityriasis rosea no. 1 & 44 & N.D. \\
Pityriasis rosea no. 2 & 32 & 0 \\
Nasopharyngeal carcinoma no. 1 & 62 & 7 \\
Nasopharyngeal carcinoma no. 2 & 63 & 0 \\
Nasopharyngeal carcinoma no. 3 & 63 & 5 \\
SLE no. 1 & 59 & 10 \\
SLE no. 2 & 84 & 15 \\
SLE no. 3 & 69 & 0 \\
SLE no. 4 & 71 & 0 \\
SLE no. 5 & 65 & 0 \\
\hline
\end{tabular}

apercentage inhibition by ERIT. Serum dilution ; $1: 4$.

bNot done.

of OKT $-4 / \mathrm{OKT}-8$ by sera from 2 patients with viral exanthema, 2 with pityriasis rosea and 4 with SLE were increased compared with those of healthy controls. Significant differences were found between patients with viral exanthema $(p<0.025)$, pityriasis rosea $(p<0.001)$, or with SLE $(p<0.005)$ and healthy controls (Table II). In contrast, low killing ratios of OKT $-4 /$ OKT -8 by sera from 3 patients with NPC were shown. A significant difference was found between NPC patients and healthy controls $(p<0.001)$ (Table I).

Table II Killing ratios of OKT $-4 /$ OKT -8 by sera from patients with viral and related diseases and SLE.

\begin{tabular}{lccc}
\hline \multicolumn{1}{c}{ Serum from } & $\begin{array}{c}\text { OKT-4/OKT-8 } \\
\text { killing ratio }\end{array}$ & P value \\
\hline Viral exanthema $\quad(\mathrm{n}=3)$ & $1.38 \pm 0.37 \mathrm{c}$ & $<0.025$ \\
Pityriasis rosea $\quad(\mathrm{n}=2)$ & $1.33 \pm 0.10$ & $<0.001$ \\
Nasopharyngeal carcinoma & $(\mathrm{n}=3)$ & $0.79 \pm 0.03$ & $<0.001$ \\
SLE ( $\mathrm{n}=5)$ & & $1.29 \pm 0.18$ & $<0.005$ \\
Healthy control $\quad(\mathrm{n}=10)$ & $1.00 \pm 0.07$ & \\
\hline
\end{tabular}

${ }^{a}$ Killing ratios of OKT $-4 / \mathrm{OKT}-8$ by patient's sera were calculated and compared with those of healthy controls.

bP values were evaluated in comparison with healthy controls by Student's t-test. $c^{\prime} \pm$ S. D. 


\section{Discussion}

Our results indicate that T-LCA present in viral exanthema, pityriasis rosea and SLE may be preferentially directed against OKT-8 (suppressor/cytotoxic) positive $\mathrm{T}$ cells, whereas those of NPC may be preferentially directed against OKT-4 (helper/inducer) positive $\mathrm{T}$ cells. It is also noted that patients with NPC produce T-LCA.

Most studies of T-LCA from SLE patients have emphasized cold-reactive IgM antibodies 9, 13). Our previous study indicated that T-LCA detected in viral exanthema and pityriasis rosea were similar in nature to those of SLE patients ${ }^{10)}$. The activity of T-LCA in the present study seemed to be due to cold-reactive IgM antibodies against $\mathrm{T}$ lymphocytes.

In recent studies using monoclonal antibodies to identify and isolate $\mathrm{T}$ cell subsets, T-LCA in SLE were found to be selectively reactive with suppressor $T$ cells and their precursors $8,16,17)$. Our results also inndicate that not only T-LCA in SLE but also those in viral exanthema and pityriasis rosea may be preferentially directed against OKT-8 (suppressor/ cytotoxic) positive $\mathrm{T}$ cells. Suppressor $\mathrm{T}$ cells and their precusors have been found not only in the OKT-8 positive fraction but also in parrt of the OKT-4 positive fraction ${ }^{18,19)}$. Therefore, T-LCA in SLE and probably those in viral exanthema and pityriasis rosea may react with both OKT-8 positive population and part of the OKT-4 positive population. Actually, in our study, the percentage of T-LCA reactive cells surpassed that of the OKT-8 positive cells in normal peripheral lymphocytes.

Morimoto and colleagues ${ }^{20,21)}$ reported that anti-T lymphocyte antibodies found in patients with active juvenile rheumatoid arthritis may react maximally with $\mathrm{OkT}-4$ positive $\mathrm{T}$ cell population. Our results also indicate that T-LCA found in NPC patients may be preferentially directed against OKT-4 positive $\mathrm{T}$ cell population. On the other hand, anti-lymphocyte antibodies in patients with AIDS have been shown against only OKT-4 positive cells ${ }^{6)}$ or against both OKT-4 positive and negative $T$ cells ${ }^{6,7)}$. Taken together with our observation, it is possible that different reactivities of $\mathrm{T}$ lymphocytotoxic antibodies with $\mathrm{T}$ cell subsets are dependent upon a variety of factors. Determination of these factors will be the subject of further research.

Nasopharyngeal carcinoma is thought to be ass ${ }^{0}$ ciated with Epstein-Barr virus ${ }^{22)}$. Although T-LCA have been reported in the sera of patients with infectious mononucleosis ${ }^{3,10}{ }^{2}$, there are no previous reports of T-LCA in the sera of patients with NPC. In this study, we detected T-LCA in the sera of patients with NPC and noted higher titers of T-LCA than in those sera of patients with viral exanthema and pityriasis rosea. Moreover, T-LCA found in NPC patients tended to maintain high activities over a period of several months (unpublished data). These facts suggest that T-LCA in NPC have biological effects on lymphocyte function which may 
influence host immunity against tumor cells. Further study of T-LCA in NPC will allow a more precise understanding of host immunity in this disease.

Finally, we have concluded from our experience that the collection of sera from patients with viral and related diseases which show high titers of T-LCA is a critical factor in future investigations because of the low incidence of these sera ${ }^{10)}$.

\section{Acknowledgements}

We thank Dr. Elizabeth M. Dugan (The Johns Hopkins Hospital) for preparation of this manuscript. This work was supported by a Grant-in-Aid from the Ministry of Education, Science and Culture of Japan.

\section{References}

1) Terasaki, P. I., Mottironi, V. D. and Barnett, E. V. : Cytotoxins in diseases, N. Engl. J. Med., 283, 724 728, 1970.

2 ) Ooi, B. S., Orlina, A. R., Pesce, A. J., Mendoza, N., Masaitis, L. and Pollak, V. E. : Lymphocytotoxic antibodies in patients with systemic lupus erythematosus, Clin. Exp. Immunol., 17, 237 243, 1974.

3 ) Mottironi, V.D. and Terasaki, P. I. : Lymphocytotoxins in diseases, I. Infectious mononucleosis, rubella and measles, in Terasaki, P. I. (ed) : Histcompatibility testing, Munksgard, Copenhagen, 1970, p. 301.

4 ) Huang, S., Lattos, C. B., Nelson, D. B., Reed, K. and Hong, R. : Antibody-associated lymphotoxin in acute infection, J. Clin. Invest., 52, 1033 1040, 1973.

5) Kiprov, D. D., Busch, D. F., Simpson, D. M., Morand, P. R., Tardelli, G.P., Gullett, J.H., Lippert, R. and Mielke, H. : Antilymphocyte serum factors in patients with acquired immune deficiency syndrome, in Gottlieb, M, Groopman J. (eds) : Acquired immune deficiency syndrome, Alan R Liss New York, p. 299, 1984.

6) Williams, R. C. Jr., Masur, H. and Spira, T. J. : Lymphocyte-reactive antibodies in acqired immune deficiency syndrome, J. Clin. Immunol., 4, 118 123, 1984.

7) Tomar, R.H., John, P.A., Henning, A.K. and Kloster, B. : Cellular targets of antilymphocyte antibodies in AIDS and LAS, Clin. Immunol. Immunopathol., 37, 37 47, 1985.

8 ) Morimoto, C., Reinherz, E. L., Abe, T., Homma, M. and Schlossman, S. F. : Characteristics of anti-T-cell antibodies in systemic lupus erythematosus; evidence for selective reactivity with normal suppressor cells defined by monoclonal antibodies, Clin. Immunol. Immunopathol., 16, 474 484, 1980.

9 ) Morimoto, C., Reinherz, E. L., Distaso, J. A., Steinberg, A. D. and Schlossman, S. F. : Relationship between systemic lupus erythematous $\mathrm{T}$ cell subsets, anti- $\mathrm{T}$ cell antibodies, and $\mathrm{T}$ cell functions, $\mathrm{J}$. Clin. Invest., 73, 689 700, 1984.

10) Hosokawa, H., Horio, S., Takiuchi, Y., Maruyama, N. and Asada, Y. : Naturally occurring T lymphocytotoxic antibody in viral and related skin diseases, Acta Derm Venereol (Stockh), 64, 275 $\sim 280,1984$.

11) Tan, E. M., Cohen, A. S., Fries, J. F., Masi, A. T., McShne, D. J., Rothfield, N. F., Schaller, J. G. , Talal, N. and Winchester, R.J. : The 1982 revised criteria for the classification of systemic lupus erythematous, Arthritis Rheum, 25, 1271 1277, 1982. 
12) Takiuchi, Y., Maruyama, N. and Hosokawa, H. : Modified method for testing human natural thymocytotoxic antibody, Arthritis Rheum, 27 : 599, 1984.

13) Koike, T., Kobayashi, S., Yoshiki, T., Itoh, T. and Shirai, T. : Erythrocyte rosette inhibition as an assay for naturally occurring $\mathrm{T}$ lymphoccytotoxic antibody in systemic lupus erythematosus, Arthritis Rheum, 22, 1064 1073, 1979.

14) Mendes, N. F., Tolnai, M. D. A., Silveira, N.P. A., Gilberston, R. B. and Mitzgar, R. I. : Technical aspects of the rosette tests used to detect human complement receptors and sheep erythrocytebinding, J. Immunol., 111, 860 867, 1973.

15) Julius, M. H., Simpson, E. and Herzenberg, L.A. : A rapid method for the isolation of functional thymus-derived murine lymphocytes, Eur. J. Immunol., 3, 645 649, 1973.

16) Koike, T., Kobayashi, S., Yoshiki, T., Itoh, T. and Shirai, T. : Differential sensitivity of functional subsets of $\mathrm{T}$ cells to the cytotoxicity of natural T-lymphocytotoxic autoantibody of systemic lupus erythematosus, Arthritis Rheum., 22, 123 129, 1979.

17) Takiuchi, Y., Maruyama, N., Hosokawa, H., Horio, S., Nasu, K., Tatsumi, E., Kita, K., Shirakawa, S. and Uchino, H. : Reactivity of neoplastic T cells to human autoantibody and monoclonal antibodies, Acta hematol JPN, 48, 99 107, 1985.

18) Thomas, Y., Soman, J., Irigeyen, D., Friedman, S. M., Kung, P. C. , Goldstein, G. and Chess, L. : Functional analysis of human $T$ cell subsets defined by monoclonal antibodies, I. Collaborative T-T interactions in the immunoregulation of B cell differentiation, J. Immunol., 125, 2402 2404, 1980.

19) Thomas, Y., Rogozinski, L., Irigoyen, O. H., Friedman, S. M., Kung, P. C., Goldstein, G. and Chess, L. : Functional analysis of human $\mathrm{T}$ cell subsets defined by monoclonal antibodies, IV. Induction of suppressor cells within the OKT $-4^{+}$population, J. Exp. Med., 154, 459 467, 1981.

20) Morimoto, C., Reinherz, E. L. , Borel, Y., Mantzouranis, E., Steinberg, A. D. and Schlossman, S. F. : Autoantibody to an immunoregulatory inducer population in patients with juvenile rheumatoid arthritis, J. Clin. Invest., 67, 753 761, 1981.

21) Morimoto, C., Reinherz, E. L., Borel, Y. and Schlossman, S. F. : Direct demonstration of the human suppressor inducer subset by anti-T cell antibodies, J. Immunol., 130, 157 161, 1983.

22) Henle, W. and Henle, G. : Evidence for an etiologic relation of the Epstein-Barr virus to human malignancies, Laryngoscope, 87, 467 473, 1977. 